Historic, Archive Document

Do not assume content reflects current

scientific knowledge, policies, or practices. 



\section{TWENTIETH ANNUAL CATALOG}

\section{AND ANNOUNCEMENT OF}

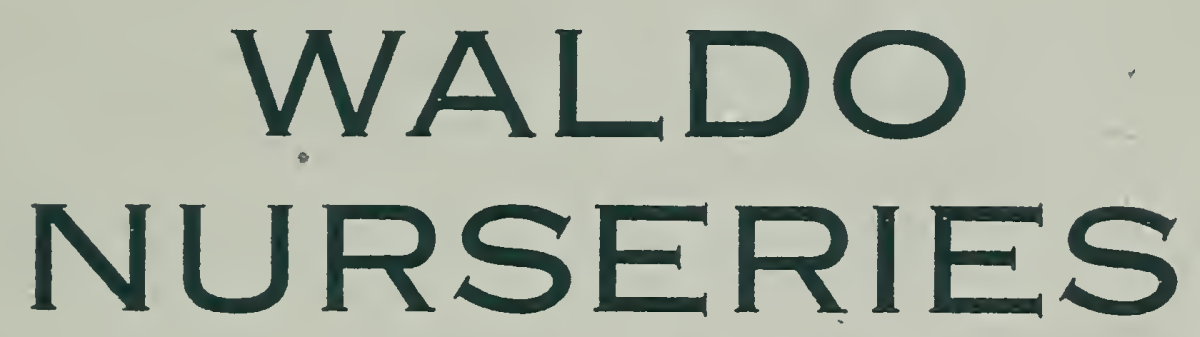

T. K. GODBEY, PROPRIETOR

ESTABLISHED 1889

WALDO, FloridA

ALACHUA COUNTY

1916

CONTAINING VALUABLE INFORMATION ON PLANTING. CULTIVATION AND KEEPING OF SWEET POTATOES $Q$

SPECIALISTS IN

SOUTHERN PLANTS

AND SEEDS 



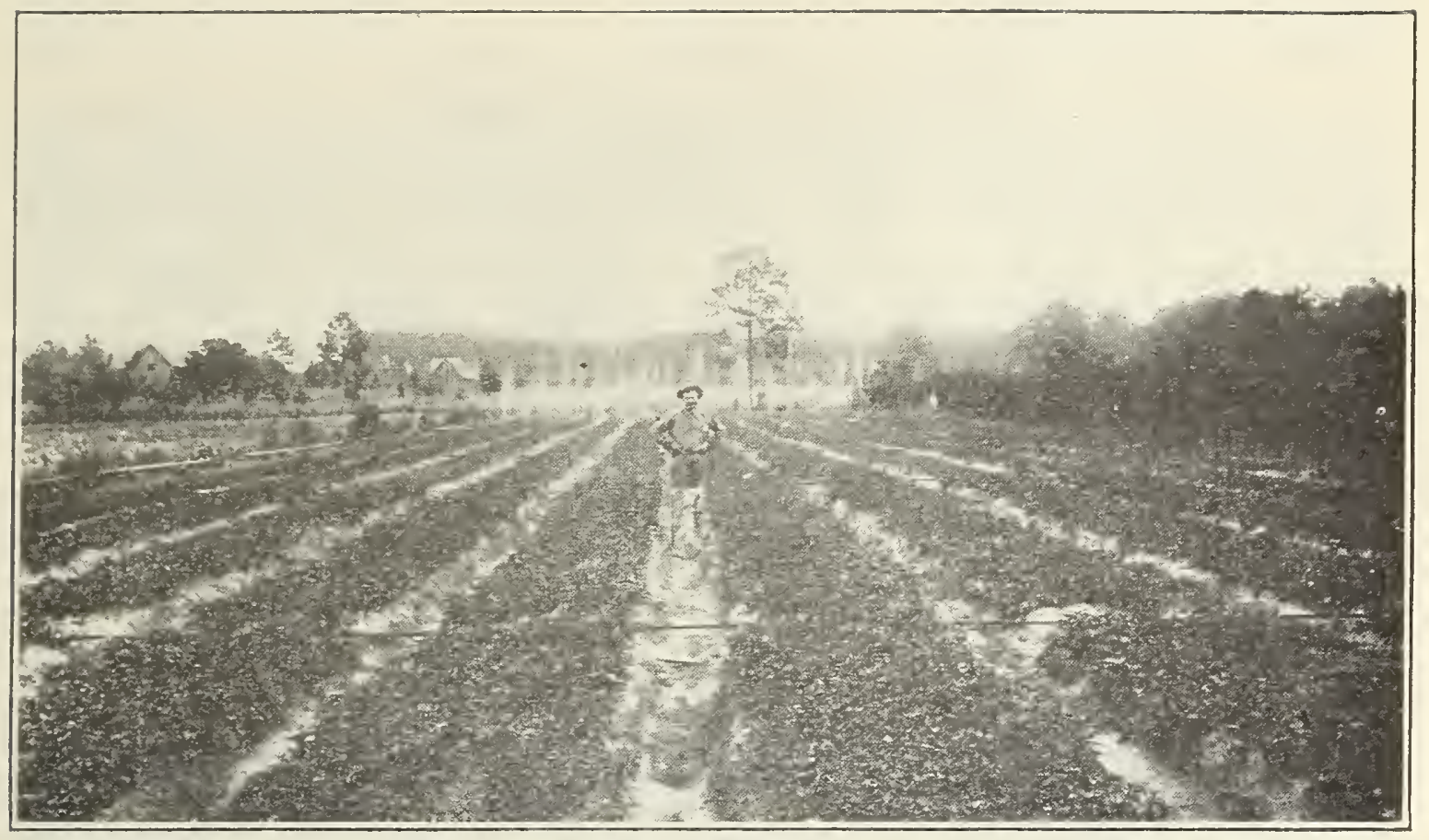

Sweet Potato Beds, containing 4000 bushels. Irrigation sprinklers flowing in background

I am absolutely the pioneer in the sweet potato business, being the first producer of these plants on a commercial scale and for many years the only commercial grower of the different varieties of sweet potato plants.

I am not a jobber of plants and seeds; I am a grower and producer, raising from my own lands the products I have to sell, and catering, especially and directly, to the Consuming Public.

Two years ago I turned over

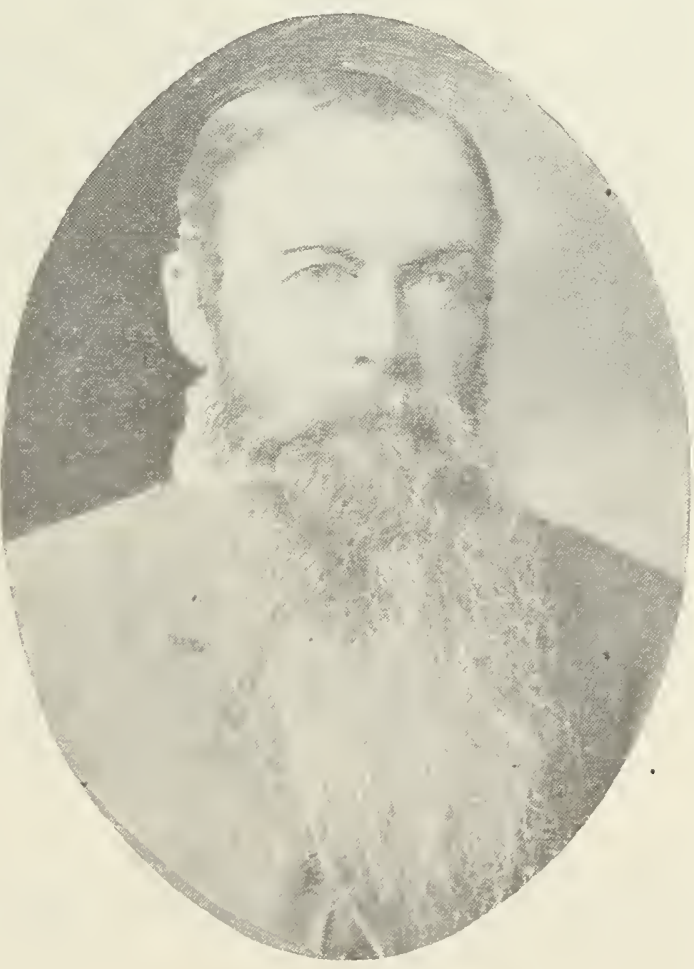

T. K. GODBEY

The man who has given the greater part of a very industrious and intelligent life towards making this business one of real service to the people who get their living by tilling the soil the Sweet Potato department of my business to Mr. J. B. Pre. vatt, but this change has proven unsatisfactory, and I have again resumed full control and owner. ship of the same and will serve my customers as formerly with the best sweet potato seed and plants that can be grown.

Please address all communications to T. K. Godbey. 
TO OUR FRIENDS AND CUSTOMERS. We believe we have the best set of customers in the world, and we wish every one of you could come and visit our grounds and see our work in every department, for we have nothing whatever to conceal and no secrets. Everything is open to public inspection, but as only a few of you can visit us, we will visit you, with cuts taken from photographs of scenes on our farms, and a plain statement of our facilities and method of doing business.

It is with pleasure we greet you with our twentieth annual catalogue. We wish to thank you for the many orders you have given us; the kind words you have spoken about us, and we assure you that every order has been filled as near the date wanted as our supply of stock and weather conditions would permit. We have had no idle hours, but have been right on the job all the time.

Now plant growing is a very peculiar business; it deals entirely with the future, which none of us can see. It also requires more skill, patience and knowledge of plant life and the diseases and the insects that affect them than any other branch of farming.

Plants can not be grown and lain upon the shelf ready to go out at a moment's notice, like a merchant handles his goods, but the supply must be kept in the ground in good condition for planting; free from disease and insects; not so old or so young to be unsatisfactory to the buyer, and all managed so as to meet the right weather conditions, over which we have no control.

PLACE YOUR ORDERS EARLY. We give this advice for your own good. The seed we use is very expensive, and the plant grower can not afford to put a great quantity of expensive seed in the ground with no prospect of selling his plants. By giving us your order far in advance of planting time, we can give you better plants, at lower prices, and fill your orders nearer the date warted, than we can if you delay sending in your order until it is too late for us to make provision for your needs. This is very evident to every practical farmer. We are heavy buyers ourselves of seed, and other supplies used in our business, and we place our orders a year ahead. This is the only way we can succeed.

QUALITY OF OUR STOCK. It is our aim to grow the very best plants and seeds that can be grown, and we are doing all in our power to give every one full value for every dollar they send us; but we make no attempt to compete in price with socalled plant growers who offer low grade plants at a price much lower than good plants can be grown. We have visited the grounds of many of these cheap men and found them shipping out a grade of plants that we throw away as culls.

For about ten years we had almost exclusive control of the 
sweet potato plant business, and we kept them free from disease. Then a lot of ignorant, unscrupulous men went into the business, and sold plants at a very low price. The result has been, they have scattered disease all over the country and sent out weak and worthless plants. A bushel of potatoes will only produce about 1,000 first-class plants, and this is the amount we figure on when we book your order. Let us figure a little. A bushel

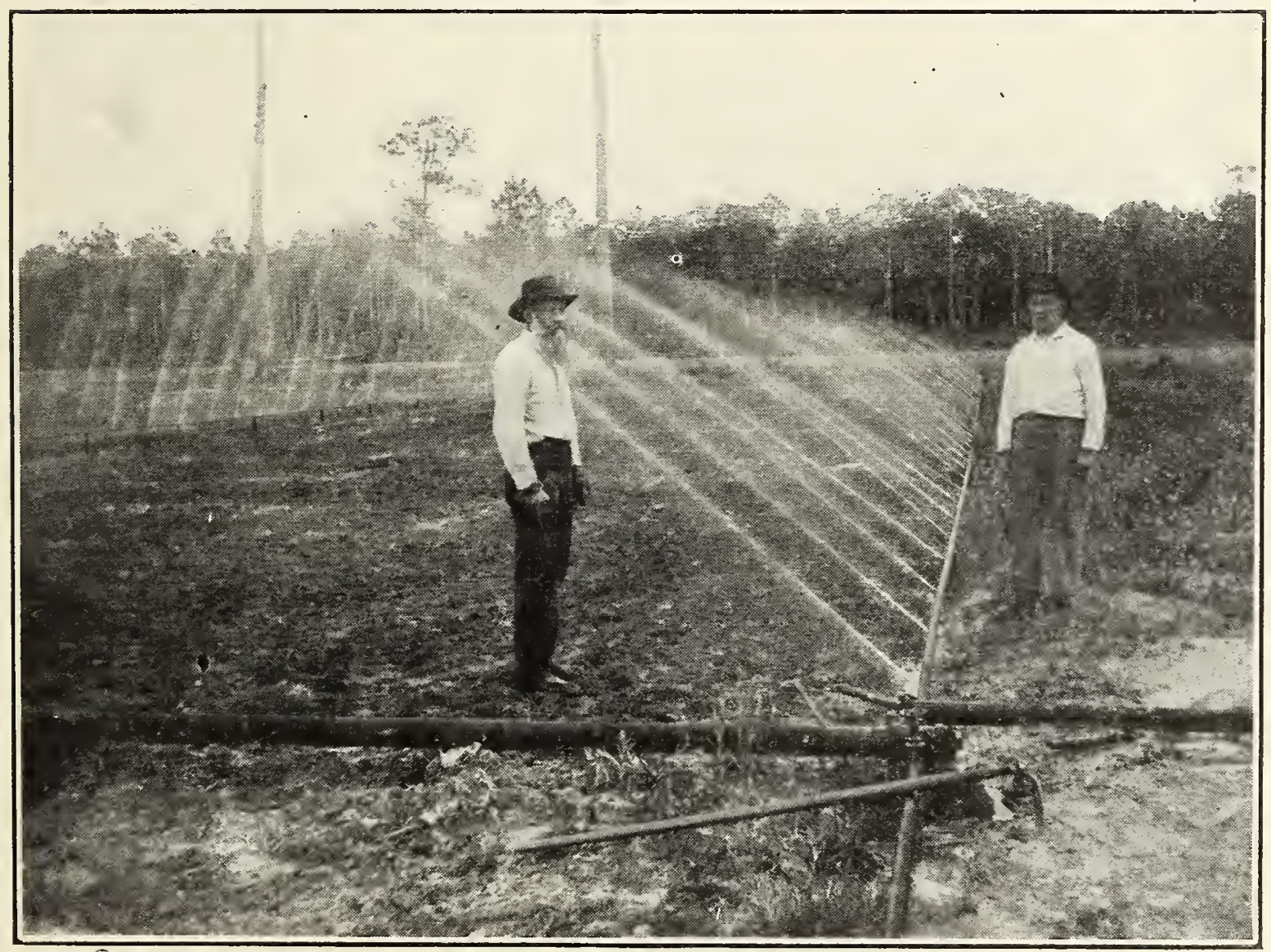

Tile Drainage and Irrigated Hummock Lands

of potatoes at bedding time is usually worth $\$ 1.25$, and often worth more; at our price for plants, $\$ 1.75$ per thousand, we only have 50 cents left to pay for bedding, pulling, fertilizer, irrigation, advertising, crates and packing. So you see the man who sells much below us must use culls and scraps and diseased potatoes that have no market value. We do not grow potatoes for table use at all, but grow them exclusively for seed, and when we are short and have to buy, we buy only the best and feed our culls to stock.

The farmer who buys the cheapest seed and cheapest plants, will hire the cheapest doctor when his wife is sick.

ACCEPTANCE OF ORDERS. When we receive your order we give it a number, enter it on our order book and send you a receipt bearing the number of your order. Your order is then re- 
ferred to the proper department for execution. Remember all orders are accepted subject to the uncertainties of the season and crops. When we ship your goods by express or freight we will notify you the same day shipment is made, but if by parcel post no notice is necessary.

OUR FINANCIAL RESPONSIBILITY. You run no risk whatever in sending us your money. . Our reputation as trustworthy and experienced plant and seed growers, covers a period of thirty years, and is vouched for by over 3,000 regular customers. We have over $\$ 20,000.00$ invested in the business and have a good rating with the commercial agencies. Just ask your banker to look us up in Dun's or Bradstreet's reports, and then ask him to look up the other fellow, who is trying to catch your order with cheaper goods. You will surely find the other fellow has no rating at all.

TERMS. Cash must accompany the order. We are too busy growing plants to look after accounts. We urge our customers to send in their orders early. Those who order in advance can secure their orders by sending $\$ 1$ with the same, the balance to be sent when plants are wanted.

COUNT. Plants are tied in bundles of 50 each. This work is done by hired help, and they sometimes make mistakes in the count. We have found bunches that had only 35 ; and others that had 70 plants. If the total count fall short, we will make good the loss; if it runs over, keep them; this is what we want them to do.

TREATMENT OF PLANTS ON ARRIVAL. If the plants cannot be set out the same day they are received, take them from the crate immediately, dip the roots in water, untie the bunches and heel out in the ground, spreading the bunches out a little. In no case should they be left in the crate.

FILLING ORDERS. We know it is useless for our customers to set a date for filling orders very far ahead, for when such a date arrives, it may be too wet or too dry, or some other cause may intervene to prevent planting at the date specified. We therefore advise you to give us about a week's notice when to ship, and if plants cannot be set immediately on arrival they can be heeled in for a few days without injury. A great many of our customers have followed this plan for many years, and it works well. Do not hesitate to write us at any time about your order, if anything goes wrong. Remember you have only one to write to, while we have over 3,000 , so do not wait on us. During the rush of plant shipping season we have to put all of our time directly into the work of getting off plants. We consider this of paramount importance. Correspondence during this period must of necessity be confined only to the essentials of the transactions. 
QUALITY OF OUR PLANTS. Our plants are all grown in the open ground, and are of the very highest quality possible to grow them, under prevailing conditions. At times the weather is more favorable for the development of plants than at others, so that the plants will vary a little in quality; this cannot be avoided. Open ground plants are far superior to hot bed, or cold frame plants, and you cannot afford to use hot bed plants as a gift, when you can get strong, open ground plants at the prices we offer them.

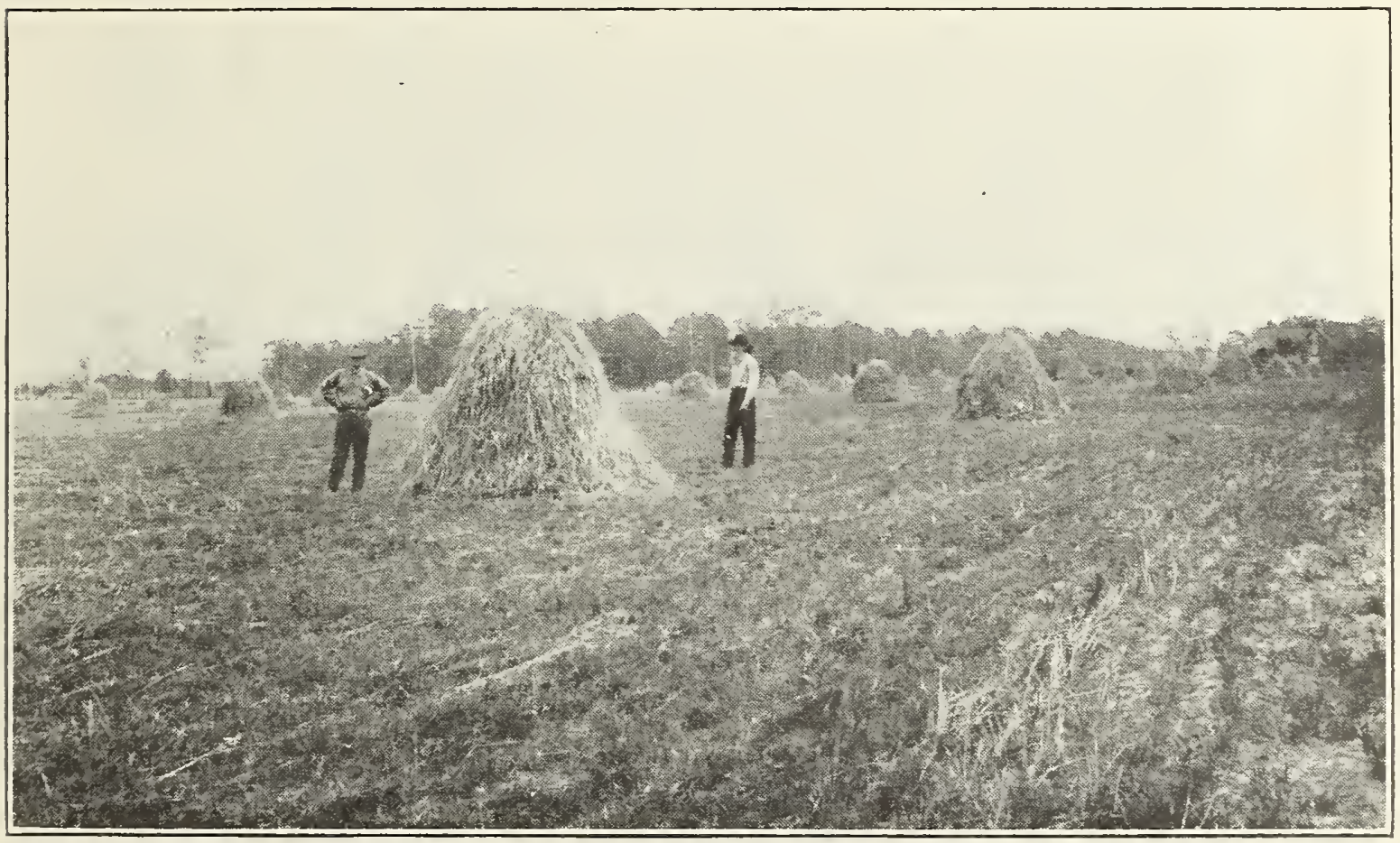

Field of Oat Hay. We plant our oat stubble in sweet potatoes.

You can profit by doing likewise

EXPRESS RATE. We have at last succeeded in getting a greatly reduced express rate, the rate having just been changed from 3 rd to 6 th class, which permits plants to go through about half the former rate. We hope our customers will greatly appreciate this, as it has required a long and persistent effort on our part to obtain this rate. It is useless to ask us just what the rate would be on a lot of plants, as they go by weight, and as this weight varies greatly according to the size of the plants, it is evident we cannot give the correct rate until the plants are packed ready for shipment.

We will ship plants by parcel post, provided you send enough to pay postage with your order. We advise such shipments to not exceed 200 plants.

You can figure the cost as follows: celery, lettuce, onion and pepper, $5 \mathrm{lbs}$. per 1,000; cabbage, beet, eggplant, strawberry and tomato, $10 \mathrm{lbs}$. per 1,000; potato, 15 lbs. per 1,000. Your post- 
master can tell you how much the postage will be from Waldo to your postoffice, provided you give him the number of pounds you want.

\section{\$300 NET PROFIT PER ACRE.}

From a commercial standpoint, the growing of sweet potatoes for the early market is a most attractive proposition. In July and August the potatoes will command from $\$ 1.50$ to $\$ 2$ per bushel and the market is never fully supplied.

Last season a grower in Baldwin county, Georgia, made a crop of 270 bushels of marketable sweet potatoes from one acre, for which he received an average of $\$ 1.50$ per bushel. His total expenditures in raising this crop did not exceed $\$ 125$, making a net profit of nearly $\$ 300$ on the acre. Some of the potatoes weighed nearly five pounds.

This farmer used the Triumph variety of sweet potato, and broke his seedbed early in January, in going twelve inches deep and harrowing thoroughly. Setting rows were laid off 4 feet apart and two weeks before setting out 700 pounds of high grade fertilizer were mixed in with the soil. Slips were put out, 5,500 plants to the acre, and well cultivated from then on. Three applications of nitrate of soda and one of guano were made during the growth of the vines. Just seventy-two days from the time the slips were set out there were tubers weighing from four to six pounds in the field. Early in July the potatoes were dug and marketed.-Atlanta Constitution.

Mr. T. K. Godbey, Waldo, Fla.

Camden, S. C., Jan. 16, 1912.

Dear Sir: Enclosed find check for $\$ 3.00$, for which please send me one bushel of Godbey's Poorland Corn. I want you to put in three or four unshelled ears in the sack, as I wish to see some of it on the cob. I ordered Triumph Sweet Potato plants from you last spring and I raised the finest I ever saw; had some to weigh $131-2 \mathrm{lbs}$; had one to measure 32 inches in length, 19 inches in circumference at the largest part, the middle, 13 inches at the top end, and six inches at the small end, which was in the ground. They took first prize at the Kershaw County Fair, and they could have easily taken first prize at the South Carolina State. Fair, had they been exhibited. I can say they are the finest eating potatoes I have ever tried, easy to cook, clear to stringy appearances. Yours truly,

W. R. HOUGH.

\section{FIFTY DAYS ON THE ROAD.}

Crocket, Texas, April 14, 1913.

Mr. T. K. Godbey, Waldo, Fla.

Dear Sir: I received the barrel of sweet potatoes Saturday, April 12th. They arrived at Crocket just a short time ago. Was pleased to get them in such good condition.

Yours truly,

W. A. EDDY.

Erie, Kansas, June 3, 1913.

Mr. T. K. Godbey, Waldo, Fla.

Dear Sir: I received your plants May 30th, in good condition. I got them set out and they are starting nicely. Thanks to you. Truly yours, JAMES WIMAN. 


\section{Field Plant Department}

\section{SWEET POTATOES}

In the production of this vegetable, Florida possesses advantages superior to any other State in the Union. When properly housed here they will keep all the year round; new and old potatoes being offered on our markets during July and August. Our

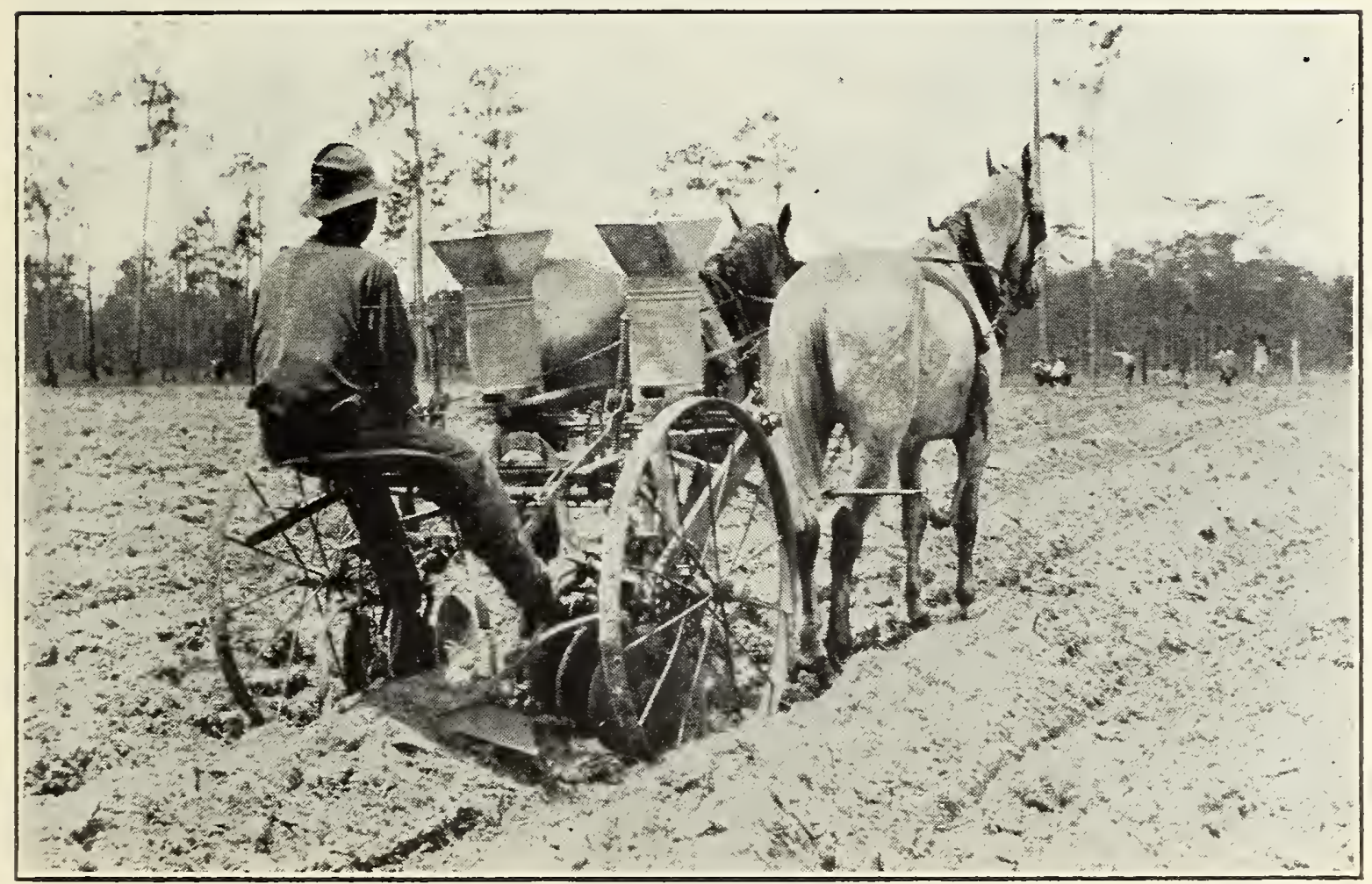

Cultivator distributing fertilizer, making up, smoothing down and center marking beds for planting sweet potatoes-all one operation

loss from rot has been less than one bushel in 100. The sweet potato also blooms and bears seeds here like a morning glory, to which family it belongs, and by planting these seeds new varieties are produced, many of which are decided improvements. Being on the northern limit of seed production, the tendency is to produce varieties of quick maturity. The Nancy Hall, Triumph, and Providence are all Florida seedlings, and are the earliest potatoes in cultivation.

After ten years' patient toil we are glad to announce that we have succeeded in producing fifteen new varieties of sweet potatoes from seed, produced by the bloom. Many of these seedlings are extra fine, and after we thoroughly test them out we will offer them to our customers. Keep your eye on this, because we have something good for you. 
It is a well known fact among truckers and market gardeners that the various seeds they use when grown in certain localities will produce a far better crop than the same kind of seed from other sections will do. For example: The best seed Irish potatoes are grown in Maine, the best cabbage seed on Long Island, the best celery seed in France, the best Bermuda onion seed on Teneriffe Island, and the best seed sweet potatoes and plants are grown in Florida. So well has this fact been established that

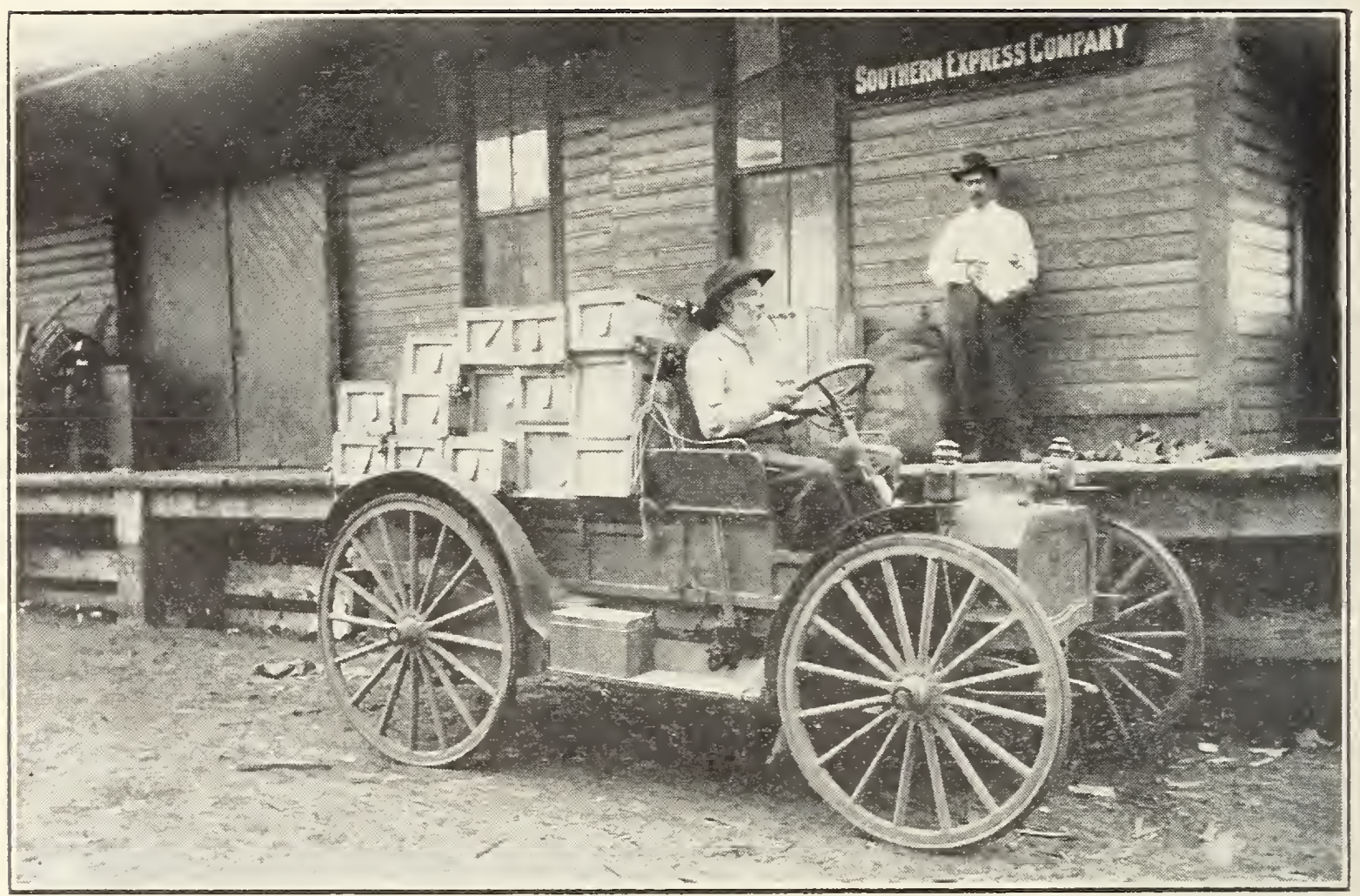

During Shipping Season

after a man has used Florida grown stock for a few years he will use no other.

For the past fifteen years we have been receiving reports from our customers that the crop harvested from Florida-grown stock was nearly twice as great, and much better in quality, than the crop grown from stock produced elsewhere.

If you want to be a successful sweet potato grower, get your seed sweet potatoes and plants from Florida.

\section{SWEET POTATO PLANTS}

Price: Small lots, post-paid, 50 cents per 100. By express, not prepaid. April delivery, $\$ 2.00$ per 1,000 ; May delivery, $\$ 1.75$ per 1,000 ; June delivery, $\$ 1.60$ per 1,000 .

Price subject to change without notice.

NANCY HALL. Tubers round or oval, smooth yellow skin, and attractive in appearance. Very early, making potatoes ready for the table in 60 days after planting. Flesh deep yellow, fine 
quality; cooks soft and sugary. Very productive, and a good keeper. Vines short.

The Nancy Hall was introduced into general cultivation by us about fifteen years ago and has become immensely popular, but is more subject to yellow blight than any other sort, and owing to the rapid spread of this disease the past few years we advise our customers to plant Triumph wherever yellow blight has made its appearance, as the Triumph is strictly BLIGHT PROOF.

GODBEY'S TRIUMPH. We are proud to say that this potato is our own production, and was the best out of a large lot of seedlings produced on our grounds about fourteen years ago. We tested it thoroughly before we named it and placed it on the market, believing it would be a winner, and its rapidly increasing popularity proves our conclusions were correct. After fourteen years' test it has proven to be the earliest, most productive, and best keeping potato in cultivation. The Triumph is oval oblong in shape, flesh light yellow, brittle and free from stringiness; cooks soft and sugary, and is of the finest quality. It has short vines, making it easy to cultivate; produces twice as much on our ground as any other sort; is strictly free from disease, and keeps all the year around. The Triumph won more prizes at the fairs last year than any other sort. It is superior to all others for canning and is planted very extensively for this purpose. Remember the Triumph originated with us, and we have the genuine stock.

The Triumph stood the wet weather this year better than any other sort, making one more triumph for the Triumph.

DOOLEY OR NORTON YAM. Also called Pumpkin Yam and Pumpkin Spanish. A well known and popular old variety.

PROVIDENCE. A fine old Florida seedling. Light red flesh, a good keeper, and a favorite with the local Southern markets.

PORTO RICO YAM. A fine new sort, deep yellow flesh, pink skin; fine form, best quality. We regard this as a much better potato in every way than the Nancy Hall. Sprouts are ready to plant from two to four weeks earlier in the spring than Nancy Hall. It matures just as quickly, is more productive, freer from disease and a better keeper. Give it a trial.

ORDER EARLY. It is very important to order potato plants very early. Some of our customers order a year ahead.

\section{EXTRA EARLY SWEET POTATO PLANTS}

For the accommodation of many of our customers who want extra early plants, we have made provision to bed a quantity of seed potatoes under canvas. These plants will be ready from March first to April 15th. It being very much more expensive to make plants this way, we cannot be expected to furnish these at the same price as other and later plants. 


\section{Early Vegetable Plant Department}

BEET PLANTS

Price 50 cents per 100 post-paid; $\$ 1.00$ per thousand by express; 10,000 for $\$ 8.00 ; 100,000, \$ 75.00$. Early varieties: Egyptian, Crosby's Improved, etc.

\section{CABBAGE PLANTS}

We are confident that we can furnish you better cabbage plants than you can get anywhere else, and our plants will stand as much cold as plants of the same age from any other section. We have been shipping cabbage plants to the States north of us for the past ten years, and they have steadily gained in popularity from the start, and the past year's trials have fully established their superiority over all others.

We have received a great many reports from parties in Alabama, Georgia and South Carolina, telling us of contests carried on by them, between our plants and those from other growers, and ours came out ahead every time. In many cases the crop from our plants was worth two or three times as much per acre as that grown from plants obtained elsewhere. Some parties report that those grown from our plants ran from 10 to 20 lbs. per head, and not a seed stalk in the field, while the same variety from other growers, planted in the same field, ran from 3 to 5 lbs. per head, and nearly half the plants running to seed.

Beware of old stunted plants grown from seed sown broadcast, and not cultivated; they can never make a good crop. Remember we sow all of our seed in rows, and cultivate the plants, which greatly enhances their value.

As to hardiness, our plants when 60 days old will stand about 18 degrees of cold, which is as much as any other will stand.

Our cabbage plants are grown from the best Long Island seed. We have a big supply ready for planting from September 1st to May 1s.t. Varieties: Jersey Wakefield, Charleston Wakefield, Early Summer, Flat Dutch, Allhead, etc.

Price of Cabbage Plants: Small lots, from 50 to 250, 40 cents per 100 postpaid; by express, not prepaid: $1,000, \$ 1.00$; $5,000, \$ 4.50 ; 10,000, \$ 8.00 ; 100,000, \$ 75.00$.

Price of plants subject to change without notice.

\section{CELERY PLANTS}

Price 50 cents per 100 post-paid; $\$ 1.25$ per thousand. 10,000 for $\$ 10$ by express. Golden Self-Blanching.

\section{EGG PLANTS}

Ready all the year. Price 50 cents per 100 post-paid; $\$ 2.00$ per thousand; 10,000 for $\$ 15$, by express. Varieties: Florida. High Bush, Black Beauty, Spineless, etc. 


\section{LETTUCE PLANTS}

Price 50 cents per 100 post-paid; $\$ 1.00$ per 1,000 , by express. All leading varieties: Big Boston, Tennis Ball, Deacon, etc.

\section{BERMUDA ONION PLANTS}

Price 50 cents per 100 post-paid; $\$ 1.25$ per 1,$000 ; 10,000, \$ 10$; $100,000, \$ 95.00$ by express.

Plants are ready from November 1st to April 1st. The Bermuda Onion is the most profitable onion grown and it can be produced successfully in all of the cotton growing states. Where the temperature does not fall below 22 they can be planted in the fall and winter, but where the cold is greater than this they should be grown as a spring crop. Onions should be planted on very rich land, in rows 2 feet apart, and 6 inches apart in the row, which requires 42,000 plants per acre. Planted this way they should make from 500 to 1,000 bushels per acre.

We have had Bermuda Onions tested in every Southern State, and every one reports splendid success. One grower reports $\$ 1,900.00$ on two acres, clear profit. They have been grown successfully as far North as Nashville, Tenn.

Bermuda Onions are so mild and sweet they take full possession of the market wherever offered. They are the easiest of all plants to ship and transplant.

Plants are far superior to dry sets for making a crop for market. The dry sets are only fit for making green bunch onions, as more than half of them will put up a seed stalk on reaching maturity, which ruins them for the market.

Write the Secretary of Agriculture, Washington, D. C., for Bulletin on Onion Culture; it is free.

Our Bermuda Onion plants are all grown from best imported seed and can be relied on to make a big crop of fine, merchantable onions.

\section{AUSTRALIAN BROWN ONION}

After repeated trials, we are convinced that this is the best onion for the Cotton Belt. It is much earlier than Bermuda. Stands more cold, and is the best keeper in the world.

Price of plants same as Bermuda.

PARSLEY PLANTS

50 cents per 100 post-paid; $\$ 1.25$ per 1,000 by express.

\section{PEPPER PLANTS}

Ready all the year. Price 50 cents per 100 post-paid; $\$ 2.00$ per thousand; 10,000 for $\$ 15$, by express. Varieties: Ruby King, Cayenne, etc. 


\section{ST. AUGUSTINE GRASS (Stenotaphrum Glabrum)}

This is unquestionably the finest of all lawn grasses for the South. It forms a dense dark green carpet, choking out all other grasses and weeds, keeping green all the year round. It is clean and smooth without mowing, seldom growing over six inches high.

St. Augustine grass is a better pasture grass than Bermuda, as it is greedily eaten by all kinds of stock, improves under close grazing, and never becomes a pest in cultivated land, as it is easily killed by plowing.

Plants should be set on clean land, 2 feet apart each way, in rainy weather. They will soon cover the land with a dense sod. 10,000 plants will set an acre. It makes no seed, but is grown entirely from cuttings. Price of plants, $\$ 1.25$ per 1,$000 ; 10,000$ for $\$ 10$.

\section{SPINACH PLANTS}

Price 60 cents per 100 post-paid; $\$ 1.25$ per 1,000 by express.

\section{STRAWBERRY PLANTS}

Our strawberry plants are all clean, healthy, nursery-grown stock, and will yield twice the berries that plants from old bearing beds will make.

Price 60 cents per 100 post-paid; $\$ 2.25$ per thousand; 10,000 for $\$ 20$, by express. Varieties: Excelsior, Klondike, Lady Thompson, and Missionary.

\section{TOMATO PLANTS}

Ready from August 1st to May 1st. Price 60 cents per 100 post-paid; from November 1st to April 1st, $\$ 2.25$ per thousand; 10,000 for $\$ 20$; from April 1st to November 1st, $\$ 1.75$ per thousand; $\mathbf{1 0 , 0 0 0}$ for $\$ 15$. Varieties: Acme, Beauty, Earliana, June Pink, Stone, and New Globe.

Mr. T. K. Godbey, Waldo, Fla.

Chipley, Fla., Jan. 23, 1913.

Dear Sir: Some years ago I secured some of your Poorland Corn, and though I have tried about a dozen other kinds since, none have come up to the Poorland. I have no recent price list, and so do not know your prices, but I want you to be sure and save me a bushel, and if you want the money before shipping, hold it and send me the hill. as I lost the seed while out of the farming business. Very truly, C. E. PLEASE.

Mr. T. K. Godbey, Waldo, Fla.

Frogmore, S. C., July 31, 1913.

Dear Sir: I wish to say that your Poorland Corn promises to be all you claim for it. It is in full roasting ear now. Planted on ordinary sandy land with about $150 \mathrm{lbs}$. guano per acre, it will make about 35 to 40 bushels per acre.

Yours truly,

W. R. PEASON. 


\section{Seed Department}

\section{COUNTING THE COST OF SEEDS.}

If you can look at seed buying as a business deal of great importance you will come closer to a profit from your labor and investment, than if you simply regard seed-buying as a necessary evil of no great consequence. So long as there are improved varieties of grain that will yield more than the varieties you have been using, you are losing money by not getting the best.

When you go to a farm auction you would not hesitate to pay more for a cow that gives a net profit of $\$ 50$ a year, instead of taking a cheaper cow that could not pay her feed bill. Yet some will buy grain or garden seed of the cheapest grade and quality, mixed with dirt and weed seed and light, chaffy seeds, and think they cannot afford to pay the higher prices for good, plump, recleaned, guaranteed seeds of the best yielding varieties.

Farming is a business that should be conducted in a business-like manner. You have no more right to cheat yourself out of profits at harvest time by sowing poor quality seeds than you have to allow any man to cheat you in a deal, or to allow at tramp to steal from you.

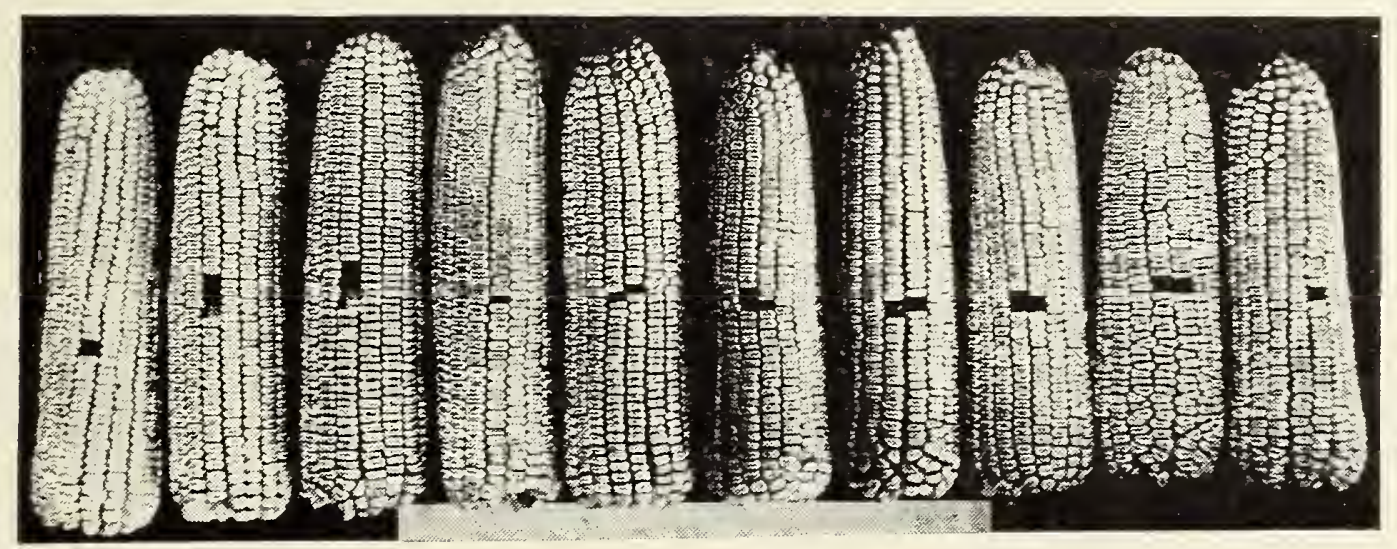

Ten Prize-Winning Ears of

\section{GODBEY'S POORLAND CORN}

In the production of corn the South is very much behind the rest of the United States. This is due mainly to the poor quality of seed used. The Southern farmer pulls the fodder from the stalk before the corn is ripe, a practice followed nowhere else, causing the grain to ripen prematurely, weakening its vitality, and rendering it unfit for seed.

Such seed when planted has a tendency to produce large stalks. with long snouty husks and very little grain.

"I was raised in the best corn growing section of the West, 
where corn is king, and where corn-breeding is a perfected science. I have been farming in the South for thirty-two years, and by carefully selecting my seed corn, year after year, with the object of increasing the amount of grain in proportion to the amount of stalk, I have succeeded in producing a strain of corn that now yields more than twice as much per acre as the corn usually planted by the Southern farmers. I have not only doubled the yield, but have also improved its weevil-resisting qualities, until it is now nearly weevil-proof."

We now offer this corn for seed, knowing it to be the most productive, nearest weevil-proof, and the best milling corn in the South.

Godbey's Poorland Corn is white, slightly tinged with yellow; weighs 62 lbs. per bushel, and makes the best of bread.

This corn was selected by the State manager of the Cooperative Demonstration Work, as the best seed corn in the State, and is also the only sort used in the public school contest. We also received an order from the U. S. Department of Agriculture for 17 bushels of this corn for distribution in the Philippine Islands.

Whenever a man produces something extra good it is sure to be imitated. Some seedsmen have gotten hold of our corn and are offering it under the name of WEEVIL PROOF CORN with their own name attached. Well, you know those who cannot originate have to imitate. Better get your seed corn direct from the originator, and then you will be sure of the genuine.

We are constantly improving on Godbey's Poorland Corn by every effort known to science. Our fields of growing corn are kept isolated, we are making our selection more rigid each year, and our mechanical means of curing, grading, and handling the seed are modern in every way.

Give Godbey's Poorland Corn a trial. You will find it a great improvement. Price $\$ 1.00$ per peck; $\$ 3.00$ per bushel. Special prices on 10-bushel lots.

\section{SEED SWEET POTATOES}

Price $\$ 1.25$ per bushel, heaping measure; $\$ 3.50$ per barrel of 3 bushels, by measure.

We are prepared to furnish a large supply of strictly pure seed potatoes, to those desiring to grow their own plants. It is a great advantage to have your own plan at home, when the weather is favorable for planting. We have a great many customers that get their seed from us every year, because the sweet potato is absolutely free from disease here, and a crop grown from them is much less liable to rot, than a crop would be that was grown from seed produced in a section where rot is troublesome. Remember that good seed is the very foundation of successful farming.

Seed potatoes can be shipped by freight at a small cost. All 
orders for seed should be sent in before February 1st, as we bed out all potatoes not sold during February. We hold all seed, sold, and ship whenever our customers are ready to hed, so they run no risk of loss from rot or freeze.

Order in barrel lots to save freight.

\section{JAPANESE SUGAR CANE}

This cane is much like Ribbon cane in general habits of growth. The stalks are longer and more slender and it will stand a little more cold and matures quicker so that it can be grown at least 100 miles further North than Ribbon cane. Japanese cane makes a larger yield per acre than Ribbon cane and is equally as good for syrup. As a stock feed it has no superior. It will yield from 20 to 30 tons green feed per acre, which is two or three times as much as can be had from sorghum or corn. Not only is the yield much greater, but it is also much richer in fat-producing elements than corn or sorghum. It springs freely from the stubble, increasing in productiveness year after year from one planting. As a forage crop it may be cut three or four times a year. It is easily cured and is greedily eaten green or dry, both stalk and blades, by all kinds of stock.

PLANTING. Japanese cane should be planted in rows about 6 feet apart, dropping a piece about 1 foot long every 2 feet; which requires about 3,500 seed per acre. The canes are easily kept through the winter, as it does not take the dry rot like Ribbon cane. Price of seed cane $\$ 2$ per $1,000 \mathrm{ft}$.

Mr. T. K. Godbey, Waldo, Fla.

Mars Bluff, S. C., March 27, 1914.

Dear Sir: Enclosed please find one dollar, for which please send me one peck of Godbey's Poorland Corn. The Triumph slips ordered of you late last season, though the season here was very dry, proved all you say in their favor, both as to quantity and keeping qualities. I took down my first bank on Saturday. They had kept perfectly; not a sprout on them. Truly yours,

DUNCAN MCINTYRE.

Mr. T. K. Godbey, Waldo, Fla.

Armuchee, Ga., Feb. 2, 1914.

Dear Sir: The cabbage and onions ordered from you that I wrote about were received all O. K. Am enclosing money order for $\$ 2.00$ for which please ship me the following: 1500 Early Cabbage, 500 B. Onion. Ship as early as possible. Another season, I am going to get up all $\mathrm{my}$ orders in advance and have all cabbage shipped in one shipment. A great many plants are being shipped here from South Carolina, but there is no comparison with yours. Respectfully,

J. L. DENTON.

Mr. T. K. Godbey, Waldo, Fla.

Chattanooga, Tenn.

Dear Sir: The cabbage plants arrived in good order and we are well pleased with them in every respect. Yours truly, B. D. DAILEY. 


\section{CHINESE VELVET BEAN.}

We claim the honor of being the first farmer in the United States to discover the value of the velvet bean as a food for stock and a soil-improver, and offered the first.seed for sale for this purpose, believing we were conferring a blessing on the Southern farmer by so doing. The vast quantity of this crop now grown in the South proves our judgment was correct.

We have tested every new bean of this class: including Lyon Bean, Yokohama, and many others that have been offered

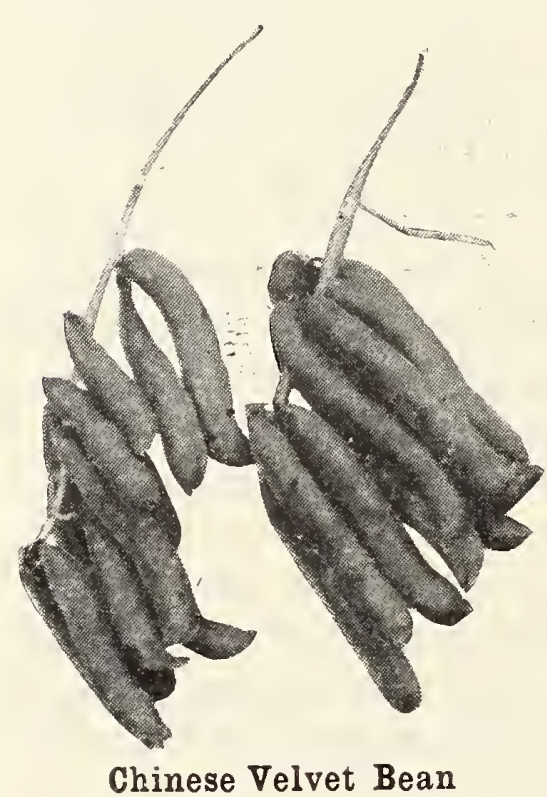

Chinese Velvet Bean in recent years, but have never offered any of these for sale, as we felt they were of no real value over the original velvet bean; but we have at last found a bean that is a decided improvement-it is the Chinese Velvet Bean. This bean is more vigorous than the velvet bean, more productive, both in vine and seed, resists the caterpillar and other insects, that often. devour the velvet bean. It will mature its seed six weeks earlier than the velvet bean, which will enable the farmers in every cotton-growing state to grow their own supply of seed. The pods and vine of this new bean are also free from the irritating hairs that are so objectionable on the velvet bean. The supply of seed of the Chinese velvet bean is very limited.

We offer this grand new bean at the following prices: Quart, post-paid, 50c. One-half peck, by express or parcel post, not prepaid, $\$ 1.00$. Bushel, $\$ 7.00$.

If you wish to try these beans order now, as the supply will all be sold before planting time.

\section{GODBEY'S 100-DAY VELVET BEAN}

This is a very early strain of speckled velvet bean, and is very desirable for late planting in the South or for early planting in the North, where the later sorts of velvet bean will not mature. Price: $\$ 2.00$ per peck; $\$ 7.00$ per bushel.

\section{GODBEY'S 130-DAY VELVET BEAN}

This bean resembles the 100 -day bean in general appearance, but makes twice as much vine and twice as many beans as the 100-day sort. Price: $\$ 2.00$ per peck; $\$ 7.00$ per bushel. 


\section{Flower Department} quoted.

All plants and bulbs in this department sent prepaid, at prices

Nothing adds more to the attractiveness of a home than a collection of beautiful flowers. The log cabin, surrounded by flowers, is more attractive to the passerby than the mansion in the desert. Flowers around a home are a sure indication of intelligence and refinement within.

God be thanked for the world-wide mission of flowers. They create the happiness of childhood and crown that of the bride; they carry our unspeakable messages of sympathy to the afflicted, and they descend into the graves of our departed loved ones.

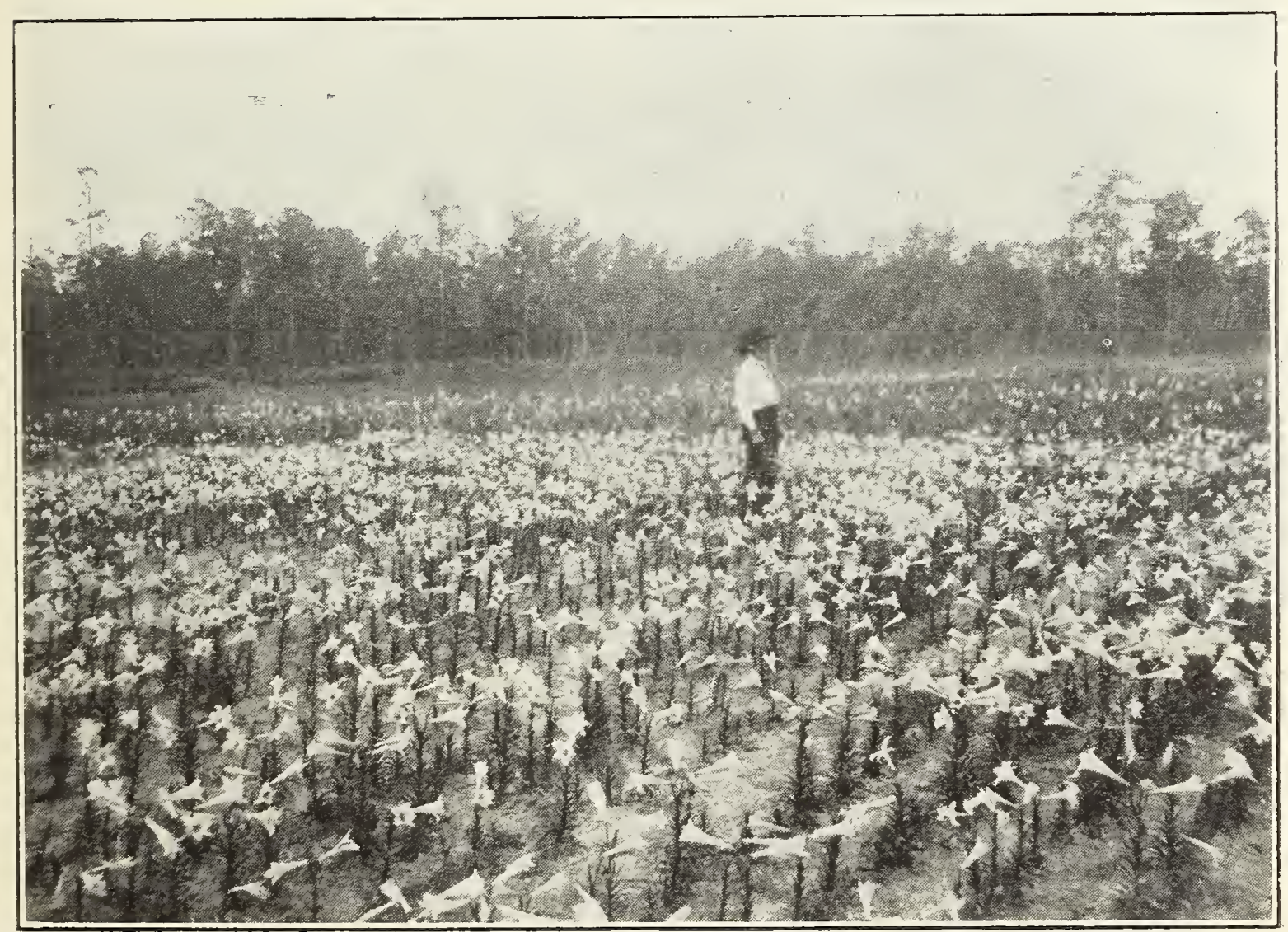

Bermuda Easter Lilies

\section{THE BERMUDA EASTER LILY}

The grandest lily in cultivation, bearing a profusion of bloom that is marvelous. The flowers are of purest waxy white and delightfully fragrant. A great favorite for both pot and garden culture.

We grow these bulbs in large quantities and offer them at about half the price asked by dealers.

Price 6 to 7 inch bulbs, $10 \mathrm{c}$ each; $\$ 1.00$ per dozen. 7 to 9 inch bulbs, $15 \mathrm{c}$ each; $\$ 1.50$ per dozen. 


\section{CALLA LILY}

This well known plant is very popular. Very easy to grow either in pots or out of doors; their one necessity is plenty of water. Succeeds fine along the edge of a running brook. Price large size roots, $10 \mathrm{c}$ each; $\$ 1.00$ per dozen.

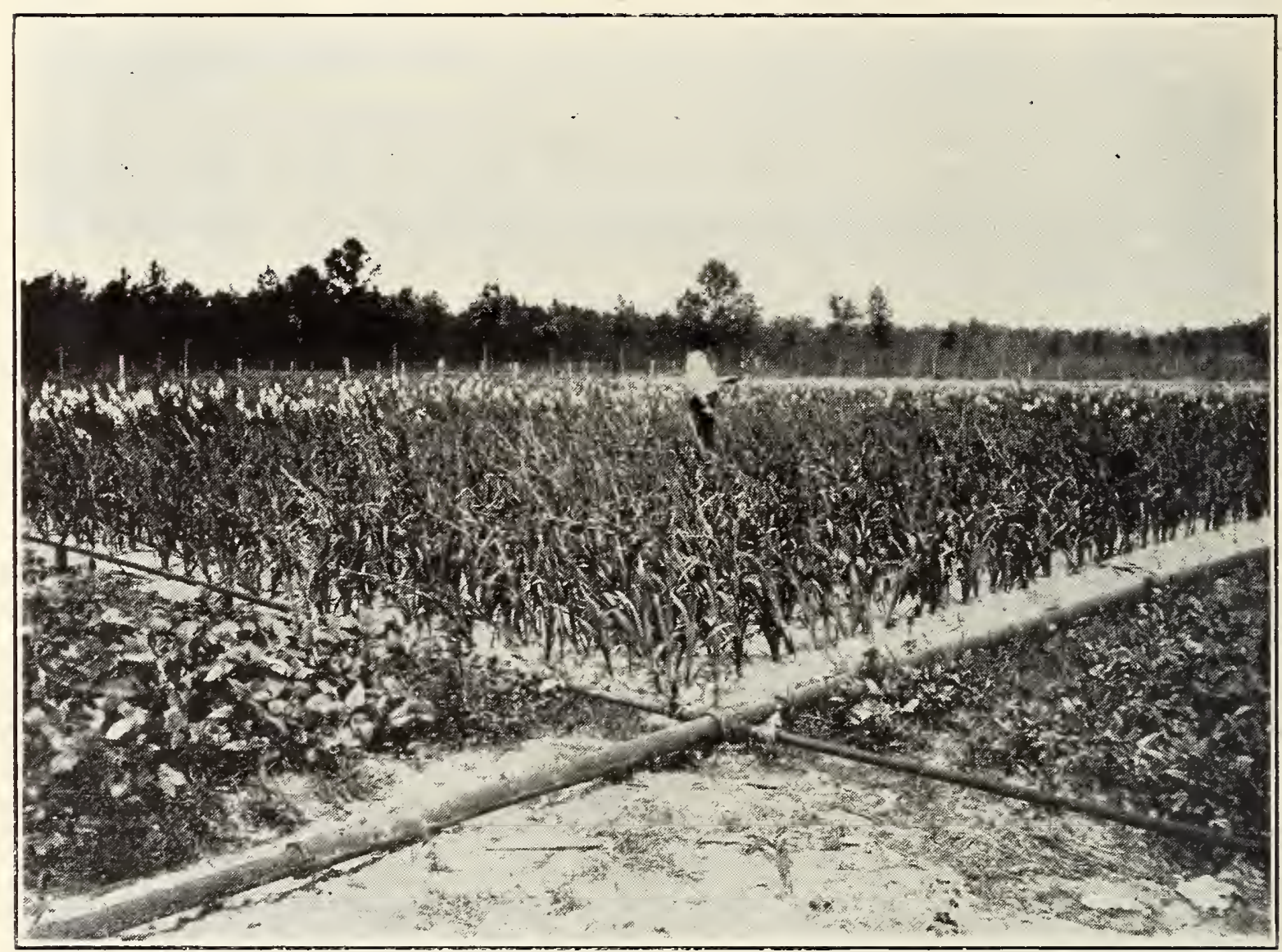

Field of Gladiolas

\section{GLADIOLAS}

We offer only the finest sorts.

America-Flower immense size, most beautiful flesh-pink. Augusta-Finest white.

Shakespeare-White and rose.

Bunchleyensis-Fiery scarlet.

Mrs. Francis King-Deep pink.

Peach Blossom-Of great beauty, soft pink.

Acermanii-Salmon orange, with white.

Price 5c each; 50c per dozen. All colors mixed 40c per dozen.

\section{TUBEROSE}

Double Pearl-White; the best variety. 5c each; 50c per dozen. 


\section{HONEYSUCKLE}

Price 5c each; 50c per dozen; $\$ 3.00$ per hundred; $\$ 25.00$ per thousand.

Aurea Reticulata (Golden Leaved). A variety with beautiful, variegated foliage of yellow, white and pink.

Chinese Evergreen-Blooms nearly all the season, deliciously fragrant, flowers buff, yellow and white.

Hall's Japan-This is the most constant bloomer of the class, being literally covered with beautiful yellow and white flowers.

Scarlet Trumpet, or Red Coral-A rapid grower, bright red, with trumpet-shaped flowers. This is the old well known variety.

\section{GELSEMIUM. YELLOW JASMINE}

Gelsemium sempervirens (Carolina Yellow Jasmine). Our native variety, with bright yellow, fragrant flowers, which are so profusely produced in early spring. Strong clumps, nursery grown, 15c each; $\$ 1.00$ for $10 ; \$ 8.00$ per 100 .

\section{GODBEY'S EVER-BLOOMING WISTARIA}

This is our own production, and is one of the most desirable climbers ever produced. It blooms full every month, from April 1st to August 1st. The blossoms are a beautiful violet blue, quite fragrant, clusters very compact, foliage dense. It is entirely distinct from any other Wistaria in cultivation. The original vine of this Wistaria was sold by us to John Lewis Childes, for $\$ 100.00$. We now offer plants to our customers for 25c each.

\section{OLEANDER} dozen.

White and pink. Price 20 to 30 inches, $25 \mathrm{c}$ each; $\$ 2.00$ per

\section{GIANT CALADIUM, OR ELEPHANT'S EAR, 25c each.}

\section{PANSY PLANTS}

We grow the finest strain of Pansy plants that can be produced anywhere. Plants of different colors, select or mixed, 50c per 100 , or $\$ 3.00$ per 1,000 , or 2,000 for $\$ 5.00$. Transplanted plants, guaranteed to be A No. 1 stock, will be mailed in lots of 25 to 100 at 1c each, postage paid. Just try a sample lot; we know you will be pleased.

\section{VIOLETS}

Beautiful, fragrant winter-flowering Violets grow and bloom during the dead of winter with no trouble whatever if given a cool situation, but will not succeed in a warm place. Many ladies are planting Violets and furnishing the cut-flower dealers of the 
cities with their supplies at a nice profit. Hardy in the South, require protection in the North.

Thrive best in a shady situation. During the winter a light covering of leaves or litter will prove beneficial.

Strong plants, $10 \mathrm{c}$ each; 3 for $25 \mathrm{c}$; $\$ 1.00$ per dozen.

Prince of Wales -The best Violets in existence. Large, heavy foliage. True blue.

Governor Herrick-Splendid new single Violet. The flowers are rich dark purple color and are carried erect on long and strong stems. For freedom of bloom this new variety outclasses all others. Very fragrant.

Violet, La France-La France stands at the head of the list. Vigorous growth, and wonderfully productive; stems 10 to 12 inches long, with large, healthy foliage; the splendid single flowers are dark rich violet-purple, size of a silver dollar, and very fragrant.

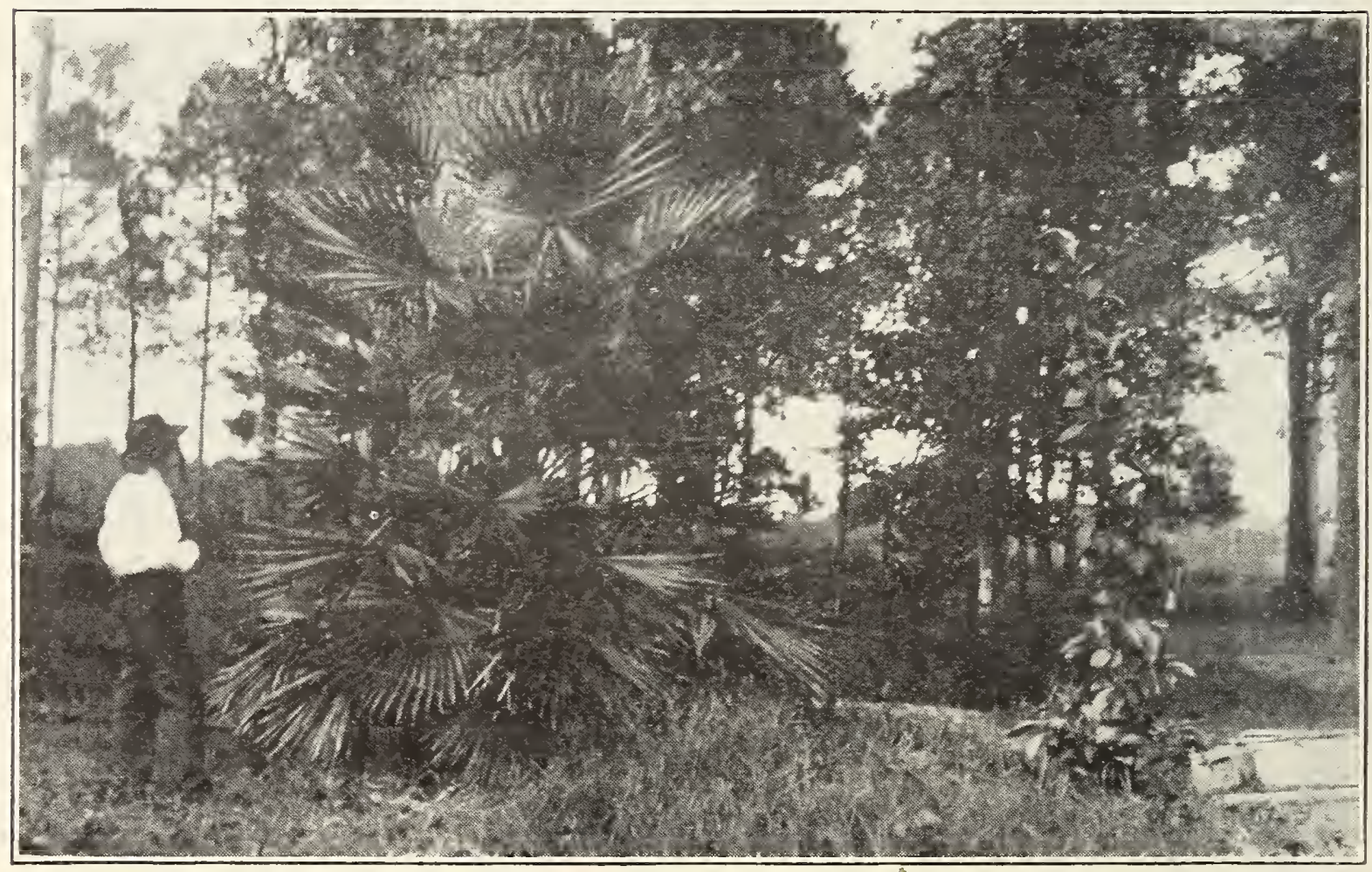

View in our grounds. Washington Palm 5 years old from seed

Mr. T. K. Godbey, Waldo, Fla South Jacksonville, Fla., June 23, 1914.

Dear Sir: Enclosed find post office money order for ten dollars and fifty cents $(\$ 10.50)$, for which reserve me six thousand $(6,000)$ Triumph Sweet Potato plants. I will wire you when I want the plants; cannot use them until it rains.

Have grown your Triumph Sweet Potato and Poorland Corn for years. There are no better varieties to my knowledge. Can you send me an Everblooming Wistaria this fall? I ordered one from you last spring and you had none in stock. Send plants to South Jacksonville, Fla., when you send them. Would like one of your catalogues, if you have one to spare.

J. M. RIPLEY. 


\section{CHINESE SACRED NARCISSI.}

Joss Flower, or Oriental New Year's Lily.

These may be grown in pots, but are more interesting and very satisfactory in bowls partially filled with pebbles and water, or in our prepared fiber. Flowers mostly white, with yellow cups; very fragrant. Extra selected bulbs, 10c each; 2 for $15 c$; 75c per dozen.

\section{NARCISSUS GRANDIFLORA.}

Also known as Paper White Narcissus. One of the most popular and easiest grown of all bulbous plants. Good for either open ground planting, for pot culture during the winter in the house, or can be grown in water, like Chinese Lilies. Our bulbs are of large size. Price 5c each; 1-2 dozen, 20c; dozen, 35c; postpaid.

Golden Spur. Uniform deep yellow. Most popular of the single Narcissi, owing to its earliness and the substance and beauty of its flowers. First-size mother bulbs. Price 5c each.

Double Von Sion. Deep yellow, very double, extra fine. Price 5c each; 40c per dozen.

Mr. T. K. Godibey, Waldo, Fla.

Cedar Town, Ga., March 7, 1914.

Dear Sir: Enclosed find check for $\$ 5.00$. Please send at once this amount in cabbage plants, large size Jersey Wakefield, and Charleston Wakefield. I will send check next for more plants and my potatoes. One more Triumph; the thermometer went down to 13 degrees and they came through O. K. Truly yours,

W. D. CRAWFORD.

Mr. T. K. Godbey, Waldo, Fla.

Girard, Ga., June 22, 1914.

Dear Sir: The potato plants I ordered from you came all right. A finer lot of plants I never saw; not a single one was dead. I have put them out and they are looking nicely. Please accept many thanks. Very respectfully,

W. H. MCNORRILL.

Mr. T. K. Godbey, Waldo, Fla.

Cullman, Ala., June 12, 1914.

Dear Sir: I write to let you know that I have received my potato slips all O. K. There was a mistake of 100 short in the first shipment, but in the second shipment there were 100 more than were billed-1650 Triumph and 50 Porto Rico Yams. You have my thanks for your prompt. ness in sending my slips. They are living and doing fine, and I am well pleased with my potato prospect. There were some other parties who ordered slips to be sent with my order-1000 I think-and if you have not already shipped them, I trust you will be able to ship them at once, as it is getting late to set them out. If I shall live I will favor you with an order for my slips another year. Wishing you success in your business, I beg to remain your friend. Respectfully, J. R. REID. Thanking you again. 
Every potato grower should have Clinton Crow's new book on Sweet Potato Culture in the South. Price, $\$ 1.00$. It is worth ten times its cost. For sale by us.

I have 700 acres of the best farm land in the State for sale on easy terms to actual settlers.

WE WILL GIVE A CASH PRIZE OF \$5.00 TO EVERY ONE WHO WINS A PRIZE AT STATE OR COUNTY FAIR NEXT FALL ON POTATOES GROWN FROM OUR PLANTS.

Please Notify us TEN DAYS BeFore YOUR FAIR OPENS THAT YOU WILL COMPETE FOR THIS PRIZE. 


\section{INDEX}

Acceptance of Orders . . . . . . .

Beet Plants

Bermuda Easter Lily ...

Caladium

Cabbage Plants

Calla Lily ......... 18

Celery Plants ...

Chinese Sacred Narcissus

Count of Plants

Corn-Godbey's Poorland Seed

Early Vegetable Plant Department 10

Egg Plant Plants........ 10

Flower Department

Field Plant Department

Gladiolas _.

Gelsemium or Yellow Jasmine._.

Godbey's Ever Blooming Wistaria .

Honeysuckle _.

Japanese Sugar Cane ...

Jasmine, Yellow . .

Lettuce Plants......

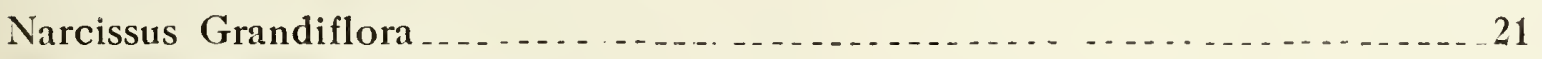

New Seedling Sweet Potatoes

Onion Plants.................. 11

Oleander

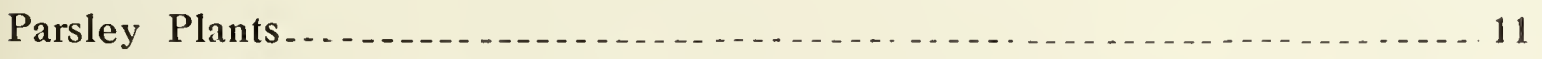

Pansy Plants

Pepper Plants....

Quality of Stock .

St. Augustine Grass . . . . $\ldots \ldots \ldots$

Strawberry Plants .

Sweet Potato Plants, Announcement

Sweet Potato Plants

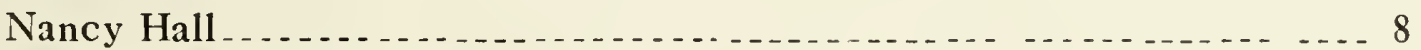

Godbey's Triumph

Norton Yam .

Porto Rico . . . .

Providence

Spinach Plants

Seed Sweet Potatoes.........

Seed Department................ 13

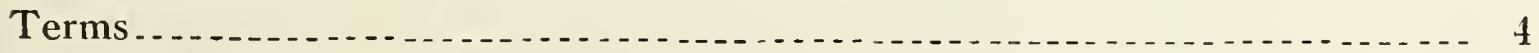

Tomato Plants

Tuberose...

Velvet Bean-Chinese

، ، Godbey's 100-Day

" " Godbey's 130-Day

Violets . . .

Pepper Pub. \& Ptg. Co., Gainesville, Fla. 



$$
\text { , }
$$


